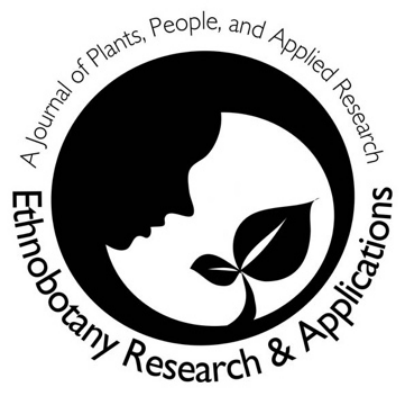

\title{
Prospects for the introduction of Ferula tadshikorum Pimentov in the conditions of the Tashkent region
}

D.T. Khamraeva, O.K. Khojimatov, Rainer W. Bussmann, A.K. Khujanov and Z.Z. Kosimov

\section{Correspondence}

\section{D.T. Khamraeva ${ }^{1,2^{*}}$, O.K. Khojimatov ${ }^{2}$, Rainer W. Bussmann ${ }^{3}$, A.K. Khujanov², Z.Z. Kosimov²}

${ }^{1}$ Tashkent State Pedagogical University named after Nizami, 100043, Chilanzar district, Bunyodkor str., 27, Tashkent, Uzbekistan

2Institute of Botany, Academy of Science of the Republic of Uzbekistan, 100125, Durmon Yoli str., 32, Tashkent, Uzbekistan

${ }^{3}$ Ilia State University Institute of Botany and Bakuriani Alpine Botanical Garden, Department of Ethnobotany, Tbilisi, Georgia

*Corresponding Author: hamraeva.dilovar@mail.ru

Ethnobotany Research and Applications 23:6 (2022)

\section{Notes on Ethnobotany}

\begin{abstract}
Background: Ferula species are used for a wide variety of purposes from the Middle East to the Himalayas. This paper provides information on the biological features and ontogenesis of the promising medicinal plant Ferula tadshikorum Pimenov during the introduction in the conditions of the Tashkent Botanical Garden.
\end{abstract}

Methods: The features of morphological development of the studied ontogenetic states were recorded during similar periods of vegetation in 2019-2021 in two variants of treatment. Under the conditions of introduction, 2 growth periods (latent, virginal) and 4 age classes (seedlings, juvenile, immature and virginal plants) were documented in plant ontogenesis.

Results: According to our study, a rapid transition from one to the next age state was found in introduced specimens. This is an important factor for the establishment of agro-coenoses needed to obtain raw material in a significantly shorter time. The results of the study show the success of the introduction of Ferula tadshikorum in the conditions of the Tashkent Botanical Garden, although the new growth conditions differed from natural soil and climatic characteristics. The collection of this species in the Garden can now serve as a basis for plantations in natural growing conditions.

Conclusion: The obtained experimental data can be used as a basis for the development of agricultural techniques and technologies for growing this plant in introduced conditions.

Keywords. Ferula tadshikorum, introduction, root, medicinal plant, monocarpic, ontogenesis.

\section{Background}

To preserve biological biodiversity and the sustainable use of natural plant resources, a primary task arises to preserve the gene pool of the most used and endangered species of the natural flora. 
Research has shown an increasing demand for herbal medicines, especially because allopathic drugs often show adverse reactions, complications, and insufficient efficacy (Ferukbo 2018; Ferukbo et al. 2010; Khasina 2018; Krasnov 2007; Saratikov \& Krasnov 2004). In oriental medicine, biologically active substances of natural origin are widely used, and the perceived advantages are low toxicity, mostly mild action, and a wide range of pharmacological activity (Khojimatov 2006, 2019,2021; Khojimatov et al. 2019).

In modern medicine, much attention is paid to the search for new sources of natural biologically active compounds, often based on ethnobotanical research, and studies on the improvement of domestic pharmaceutical production (Dayronas et al. 2018; Grebennikova et al. 2018; Kaukhova 2007). A particularly relevant issue in the search for promising plant sources for biologically active substances, is the sustainable use of natural raw materials and the need to create a domestic production of medicinal herbal preparations based on local substances.

Research on the introduction of useful and food plants into culture under various soil and climatic conditions is actively conducted to foster the development of medicinal plant production in Uzbekistan. Much attention is paid to economically promising medicinal, essential oil, honey-bearing, aromatic and other plant species, most of which were wild collected in the recent past. Introduction studies of these useful and medicinal plants make it possible to expand domestic pharmaceutical production and improve agricultural production for obtaining raw plant materials and preserve the gene pool of these species.

The choice of material suitable for introduction is especially important. In this context it is important studying the domestic medicinal market, determining the needs of the population for drugs of certain pharmacotherapeutic groups. One of such promising and poorly studied medicinal plants is Ferula tadshikorum Pimenov, which, for obtaining gum-resin, has long been subjected to uncontrolled collection and exploitation of natural populations, which eventually led to a sharp decline in the number of individuals and populations (Khojimatov et al. 2018).

Ferula tadshikorum was separated from the subgenus Narthex (Falcon.) Drude by M.G. Pimenov in 1974 (Rakhmonov 2017). According to literature data (Rakhmonov 2017), the monocarpic Ferula tadshikorum has a long life-cycle lasting 23-27 (30) years, with a juvenile period of 6-7 years, an immature age of 14-15 years, the virginal age of $24-27$ years.

To systematically identify significant anatomical features of the species, a detailed anatomical study of the fetal pericarp of Ferula tadshikorum was carried out and several diagnostic features of the fetus with taxonomic significance were identified (Khojimatov \& Khamraeva 2018). Some authors have also studied the chemical composition of underground organs for the detection of essential oils, coumarins, terpenes and other substances (Kiryalov 1980; Sharñov et al. 2019; Vandyshev et al. 1975).

To maintain stable natural populations of this medicinal species in the flora of the Republic of Uzbekistan, and to allow the establishment of plantations of Ferula tadshikorum in the natural growth environment, experimental plots were established in the conditions of the Tashkent Botanical Garden to study growth and development, sowing seeds under two different treatments. In the first treatment, plant seeds were sown at the end of the second half of November, and in the second variant at the end of the second half of December 2018 (Khamraeva et al. 2019). According to data, the best time for sowing seeds is the second half of December, because then the beginning of the emergence of seedlings coincides with the natural seedling emergence in the wild.

The purpose of this study was to document the biological features and rates of ontogenesis of regenerative plants of Ferula tadshikorum under artificial environmental conditions.

\section{Materials and Methods}

Ferula tadshikorum is a medicinal plant belonging to Apiaceae. The resin, mostly harvested from the roots, is used for medical purposes (Fig. $1 \mathrm{a}, \mathrm{b}$ ). The plant is a perennial monocarpic, 1.5-1.8 $\mathrm{m}$ tall, with a strongly pronounced garlic smell.

Ferula tadshikorum is distributed in Central Asia (Southwestern Pamir Alay) is endemic to southern Uzbekistan and Southern Tajikistan. In Uzbekistan, the species is found in the Kashkadarya and Surkhandarya regions. It grows in the middle mountain belt on loess and fine-grained-gravelly slopes, and limestones, along dry river valleys and terraces, at an altitude of $1400-1800 \mathrm{~m}$ above sea level. 
To study the ontogenetic age conditions, we used generally accepted methods (Ontogenetic atlas of plants 1997; Rabotnov 1950a,b). Observations of seasonal development and description of the life cycle of individuals was carried out according to Serebryakov (Serebryakov 1947, 1961).

During 2019-2021, two-time watering and weeding were carried out in each growing season at the experimental sites. The soil and climatic conditions of the Botanical Garden are described in Belolipov (1989). The garden is located in the north-eastern part of Tashkent at an altitude of $480 \mathrm{~m}$ above sea level. The soil is ancient rusty typical gray soil. The climate of Tashkent is sharply continental, characterized by dryness, with significant daily temperature fluctuations, hot summers, dry warm autumn and moderately cold winter. The recorded absolute minimum temperature is $-25.8{ }^{\circ} \mathrm{C}$, the absolute maximum $+44.6{ }^{\circ} \mathrm{C}$. The average precipitation is $380-440 \mathrm{~mm}$, which falls mainly in the autumn-winter-spring periods. Plants of different ages were photographed with a Canon EOS 600D digital camera.

\section{Results and Discussion \\ Traditional uses of Ferula sp. Local medicinal uses}

The communities of Central Asia use the resin of various species of Ferula as a remedy for nervous and viral diseases of the sexual system. The resin is also used as a galenic drug to alleviate symptoms such as flatulence and gut lethargy, and the species is used for the same purpose in homeopathy. In folk medicine in many countries of the east (e.g., India, Pakistan, Iran, and Afghanistan), Ferula gum-resins are used in food, to strengthen the body, get rid of pain, with ulcers of the stomach and intestine. Young leaves and generative organs also serve as medicinal parts.

Ferula assa-foetida: Resin used for epilepsy (Dey et al. 2017), digestive and respiratory disorders (Ahmad Jan et al. 2019; Alqethami et al. 2017). Employed to treat colds, cough, fever (Ballabh et al. 2007). Ferula assa-foetida is already mentioned as medicinal plant in ancient Persian texts and has spread from Iran to many other countries. For medicinal purposes the stem is removed at the end of the vegetative period, when the leaves wither, the root is uncovered, and a thin slice is removed. The root then yields a milky juice which turns brown and hardens in air. This is gathered with a part of the root and another layer is cut to obtain more milky juice. As a tincture it is used in the treatment of convulsions. In Central Asia the plant has long been used as anti-spasmodic, anticonvulsant, choleretic, for hysteria, hypochondria, bronchial asthma, pulmonary tuberculosis, diabetes, diseases liver, syphilis, malignant about lumps and topical for dermatosis.

F. assa-foetida's Oleo-gum resins extracted from the cuttings of root stock is used in folk medicine to treat respiratory problems (such as asthma, cough and bronchitis), hysteria, constipation, bad digestion and intestinal worms (Mozaffarian 2013). In north-east of Iran, it is used to relieves colic pains and as an anti-parasite. Likewise, women use the gum of this species to stimulates menstrual flow when menstruation is absent (Amri \& Joharchi 2013). The aerial part of the plant is eaten raw or dried as diuretic, antispasmodic and anthelminthic (Zargari 1990). Ferula narthex is used in Pakistan to improve eyesight, and for digestive problems (Sher et al. 2016; Ur-Rahman et al. 2019). Reported as abortifacient (Quave 2013).

In Middle Asia Ferula leaves are used as, anticonvulsant, choleretic, bronchial asthma, tuberculosis, diabetes, liver problems, syphilis, malignant tumors, vermifuge, for nervous diseases, and wounds as well as dermatoses. (Sokolov 1988).

Ferula violacea is rich in vitamins and used to aid digestion and to treat gastrointestinal problems. F. violacea is also used as a medicine to treat digestive system disorders and as an anthelminthic against gastrointestinal worms (Boboev et al., 2013).

The use of Feruka tadshikorum in folk medicine has also a centuries-old history. Since ancient times, the species has been used as an analgesic agent for arthritis and joint pain. Pharmacological studies have shown that the plant exhibits expectorant and anticonvulsant properties in exudative diathesis, pulmonary tuberculosis, otitis, lymphadenitis. Some studies have shown an effective effect of the plant in malignant tumors and syphilis $\int$, for which the leaves of the plant are mixed with acidic milk (https://planta-medica.uz/ferula-tadshikorumpimenovferula-tadzhikov/). 


\section{Local food uses}

Ferula assa-foetida. Used as spice (Gurib Fakim 2006). The starch in the root is eaten as porridge after being soaked in water to remove its odor and unpleasant taste. (Sokolov 1988).

Local people use leaves and stems in traditional foods. The smell of dried Ferula violacea is very pleasant and people use it during the winter in different meals. The fresh and young sprouts of Ferula violacea are widely used as a fresh vegetable. Leaves are used in preparing national Tajik dishes, e.g., Oshi burida, Otala, Birinjoba and Mastoba (Boboev et al. 2013, 2015).

\section{Local handicraft and other uses}

In veterinary medicine Ferula is used for wound healing. (Sokolov 1988). The fruits yield much fat and protein and are fed to horses and sheep in winter. (Sokolov 1988). In veterinary practice, a porridge obtained from the roots of Ferula tadshikorum, prepared with boiling water, is used as a wound healing agent in skin diseases of domestic animals. The population also eats young stems in spring in the form of salads and as a filling of green dolma. Leaves in dry form are used to feed cattle (https://planta-medica.uz/ferulatadshikorum-pimenov-ferula-tadzhikov/ ).

\section{Production of Ferula tadshikorum}

During our study from 2018-2021, the features of the different ontogenetic age states of Ferula tadshikorum were identified, and differences in the duration of the pre-generative period were observed in comparison with individuals from natural habitats.

First growing year. We previously studied the first growth year of Ferula tadshikorum and identified 2 periods latent, virginal and 3 age-related states in ontogenesis - seedlings, juvenile and immature plants (Khamraeva et al. 2019). In the current experiments seed germination was about $85-90 \%$. In the first year of the experiment (2019), seedlings sprouted in February-March, depending on the timing of sowing, which was consistent with natural populations (Rakhmonov 2017). In the first year, the main part of the experimental plants was in the juvenile phase of development, and only 1-3\% passed into the immature state. The aboveground part of a few juvenile plants began to dry out from the end of May, and the remaining juvenile and immature individuals in mid-late June.

The second growing year. The second growing season began at the end of the first decade of February, when the air temperature rose to $5^{\circ} \mathrm{C}$. Most individuals remained viable in the second year of development, only $5-10 \%$ of all plants died. At two experimental sites, by the end of the second decade of February, the plants were actively laying leaves and accelerated growth could be observed. By mid-March, according to the morphological structure of the leaves of experimental plants, both juvenile and immature individuals could be distinguished, and in the further development of the plants, an increase in the aboveground and underground parts was observed. By this time immature age individuals predominated. In juvenile plants, simple leaves did not differ in appearance from the first year, but the plants showed a single scaly leaf from 4 to $6.5 \mathrm{~cm}$ in length. During growth, 1-3 (5) rosette leaves were formed on the rosette shoot. Rosette leaves varied in length, from 14 to $24 \mathrm{~cm}$, leaf blade $9-12 \mathrm{~cm}$ long, 4-5 $\mathrm{cm}$ wide, petioles $5-12 \mathrm{~cm}$ long. The main root was $10-17 \mathrm{~cm}$ long, with a tuberous apical part thickening to 0.6 $\mathrm{cm}$, and a basal part diameter of $0.2-0.3 \mathrm{~cm}$.

At the end of the second decade of May, most individuals, with the exception of a few (about $10-15 \%$ of juvenile ones), were in an immature state. Immature plants of the second year of life had 1-2 scaly leaves 7-11 cm long, which quickly faded after the appearance of rosette leaves. On the rosette shoot, these individuals formed from 3 to 6 leaves, of which 1-2 were simple and 2-3 triple-dissected. Some individuals had 1 more leaf with a more complex-5-6-lobed plate. In triple-dissected leaves were obovate or broadly oval lobes, with a leaf blade 15-26 cm long, a petiole of 12-16 cm long. The 5-6-lobed leaves had elongated-oval, ovate or broadly ovate segments, the leaf blade was more broadly triangular in outline, up to $27 \mathrm{~cm}$ long, the segments $10-16 \mathrm{~cm}$ long, 4- $6 \mathrm{~cm}$ wide, and the primary segments with short petioles, while the others were sessile, with a petiole up to $14 \mathrm{~cm}$ long.

In immature plants, the root system was deep-rooted, consisting of the main and lateral roots, as well as thin ephemeral roots. On the main root in the basal zone, the transverse folds were more numerous, with $2-3$ cylindrical thickened and 3 somewhat thin lateral roots. The length of the main root was $28-32 \mathrm{~cm}$, its diameter in the basal part up to $1.8 \mathrm{~cm}$, in the thickened zone $2-2.5 \mathrm{~cm}$. The length of the thickened lateral roots was $20-25 \mathrm{~cm}$, the diameter in the thickened part about $2 \mathrm{~cm}$, and the thin lateral roots were $15-17 \mathrm{~cm}$ long. Starting from the end of May and continuing until mid-June, the plants finished the growing season and went to rest. 
The third growing year. In the third year, plants developed a little earlier, i.e., in early February, because in 2021 the air temperature already exceeded $5^{\circ} \mathrm{C}$ at the end of January. During this growing season, as in the previous year, many individuals remained viable, except for $5-7 \%$ of who died. All plants of different ages of this growing season had scaly leaves, juvenile individuals one, and the remaining individuals 1-3.

Juvenile plants made up a very small part, i.e., about 5-10\% of the total number of experimental plants in the third year. Overall, 1-3 rosette leaves were formed on the rosette shoot (Fig. 1c). According to the structure of the leaf and underground organs, juvenile individuals were like the same individuals of previous years, but slightly larger. The leaf length reached $17-31 \mathrm{~cm}$, the leaf blade was $10-15 \mathrm{~cm}$ long, 5-6 cm wide, and the petiole 7-16 cm long (Fig. 1d).

Immature individuals represented $70-75 \%$ of all plants and were dominant age state in both variants of the experiment. According to the characteristics of the leaves, they differed from immature plants of the second growing year by the presence of either a triple-dissected or a leaf with a 5-6-lobed plate in the number 1-2, and did not have simple leaves (Fig. 2e, f). In addition, their root system became deeper and somewhat enlarged.

Virginal plants of the first year of life accounted for $10-15 \%$ of the total number of experimental plants. In virginal plants, once or twice pinnately dissected leaves, were formed in the rosette, in the number of 2 or $3,45-57 \mathrm{~cm}$ long, the petiole is $17-25 \mathrm{~cm}$ long (Fig. $2 \mathrm{~g}, \mathrm{~h}$ ). The leaf blade was broadly triangular in outline, the leaf segments were elongated-oval, broadly ellipsoidal, $5-30 \mathrm{~cm}$ long, $3-8 \mathrm{~cm}$ wide, the primary segments were on short petioles, the rest were sessile.

Virginal plants were characterized by a deep-rooted root system. The main root was $35-48 \mathrm{~cm}$ long, spindle-shaped, the bark was dark brown, the diameter in the thickened zone was 3-3.5 cm, with remnants of petioles of last year's leaves. In virginal individuals, no thickening of the lateral roots was observed, and all organic substances were deposited the main root. The plants went to rest starting from the end of May.

According to the results of 2019-2021, juvenile plants showed simple leaves in different numbers, immature individuals had more complex leaves from the second year of life, accompanied by an increase in the size of the root system. The third growing season was characterized by the transition of some immature plants to the virginal stage of development. That is, there is an intensive development by reducing the life expectancy of each age condition, but in the 2019-2021 years of observation, the duration of the vegetation period in two variants was almost close. Based on the results obtained, it can be concluded that the introduction of Ferula tadshikorum in the new conditions was successful and that there was a reduction of each ontogenetic age state. According to our results, plants already went into the virginal phase of development in the 3rd year, in contrast to natural populations where this stage was only observed after 10-13 year of life and before flowering (Rakhmonov 2017).

Most of species Ferula in Central Asia, are ephemeroids, that is, perennials with a short annual period of growth and development and a long rest period falling at an unfavorable time of the year due to the hot and dry summer (Korovin 1947; Safina \& Pimenov 1984). Similarly, in Ferula tadshikorum, growth in natural conditions begins in early spring and ends at the very beginning of summer (Rakhmonov 2017). Our data also confirm the above, since the short duration of the growth period, which falls on a wet spring, in the mesoxerophyte Ferula tadshikorum is compensated by a significant intensity of the passage of ontogenetic age conditions, especially in introduced conditions and rapid growth processes.

Botanical gardens are ideal sources of seed and planting material for useful (medicinal, decorative, forage, technical), rare and endangered plant species for introduction into agricultural production. As example, the Central Botanical Garden of the National Academy of Sciences of Belarus served as source of about 35 species of medicinal and spicy-aromatic plants that were introduced into wider cultivation. As a result, imports for the pharmaceutical industry decreased, because the local raw materials almost completely satisfied the needs of the local food industry. In addition, more than 40 biomedicines and more than 20 new food ingredients were produced on the basis of these plants, reducing the import of spices, flavorings, and preservatives of chemical origin (Titok \& Volodko 2012).

Because the various biologically active substances in the gum-resin of Ferula tadshikorum are only deposited in later life stages, resin can be obtained no earlier than 4-5 years after sowing seeds in new plantations, depending on the climatic conditions (precipitation, snow cover). We consider the optimal collection of gum should start from 
5-6-year-old plants. At the same time, it is necessary to retain at least $20-30 \%$ of the adult plants, to obtain seeds for future crops and the natural renewal of populations.

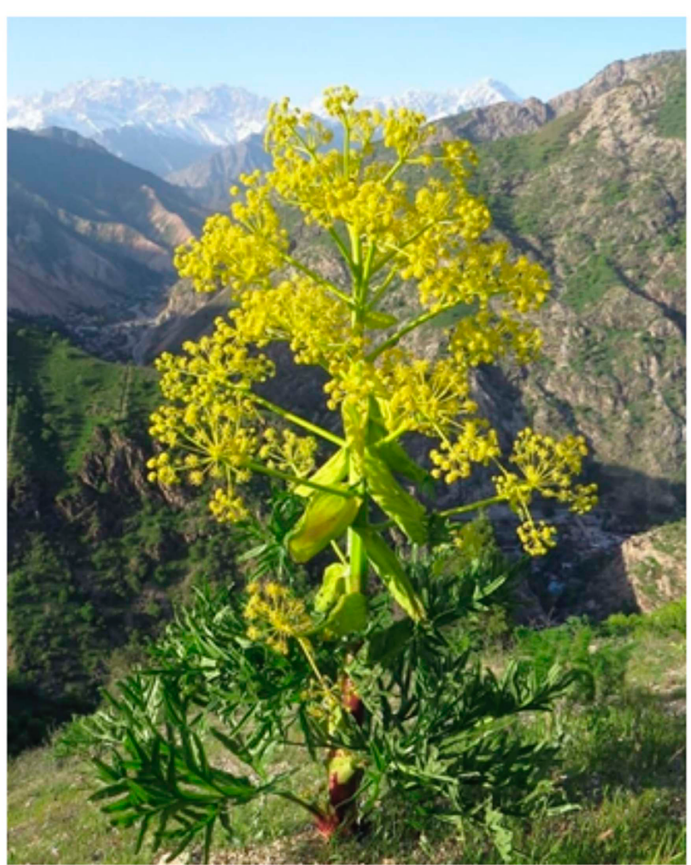

a

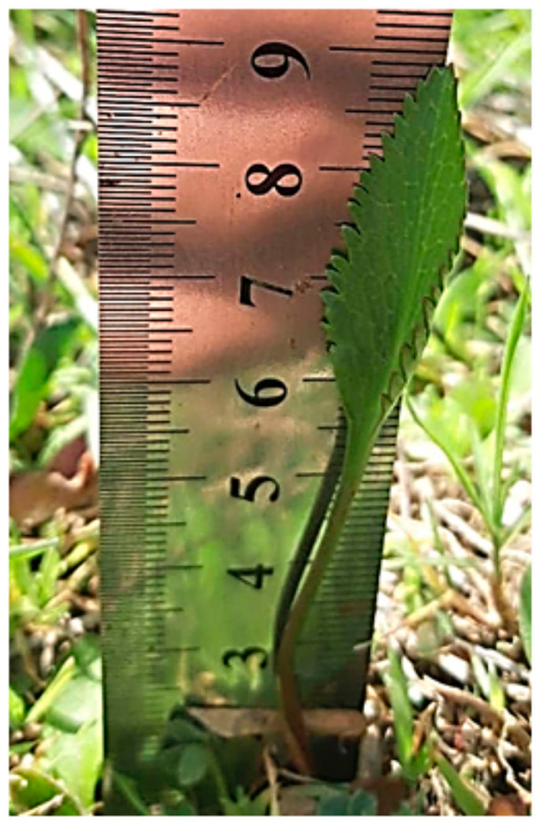

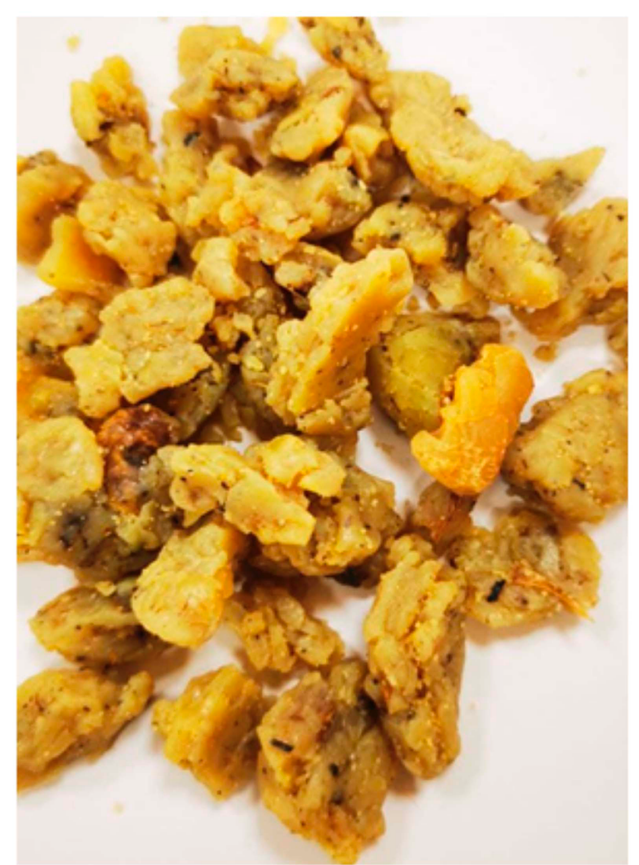

b

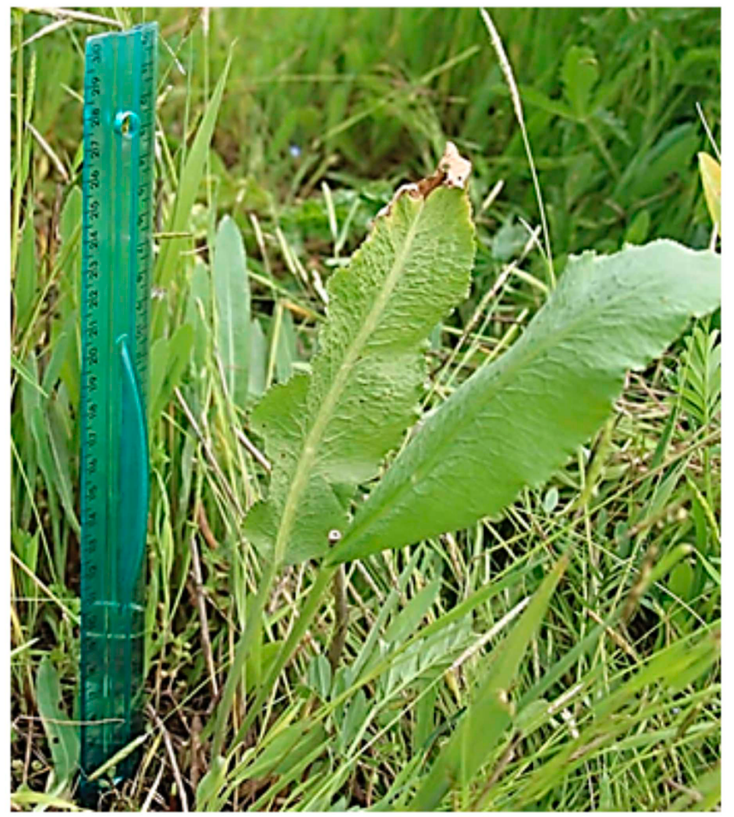

d

Figure 1. Different-age plants of Ferula tadshikorum. a - generative plant in natural conditions, b - general appearance of the resin, c - juvenile plants of the third year (18.02.2021), d - juvenile plants of the third year (22.04.2021). 


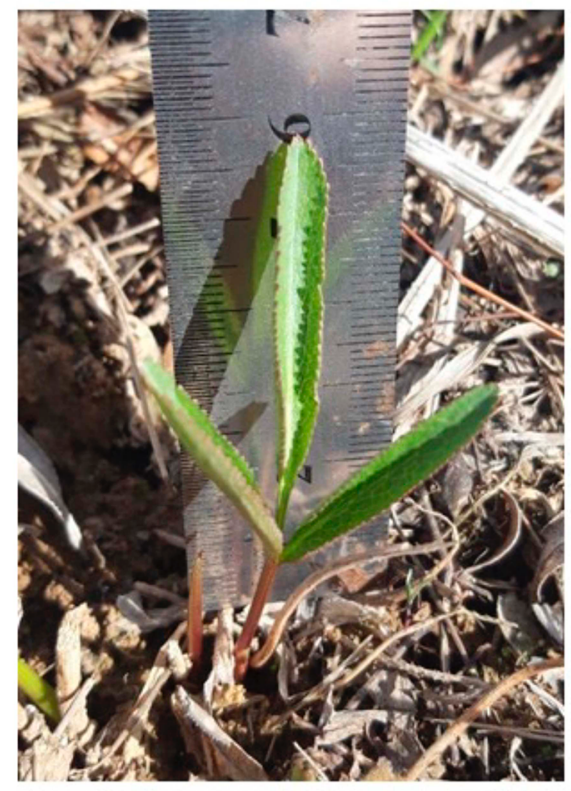

e

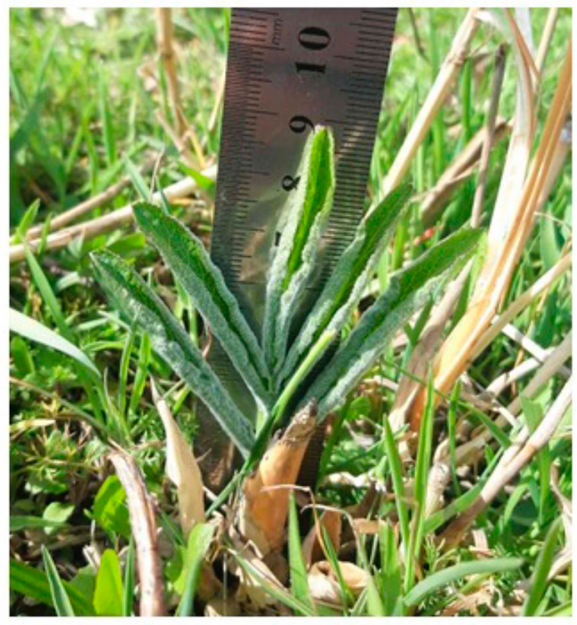

$\mathrm{g}$

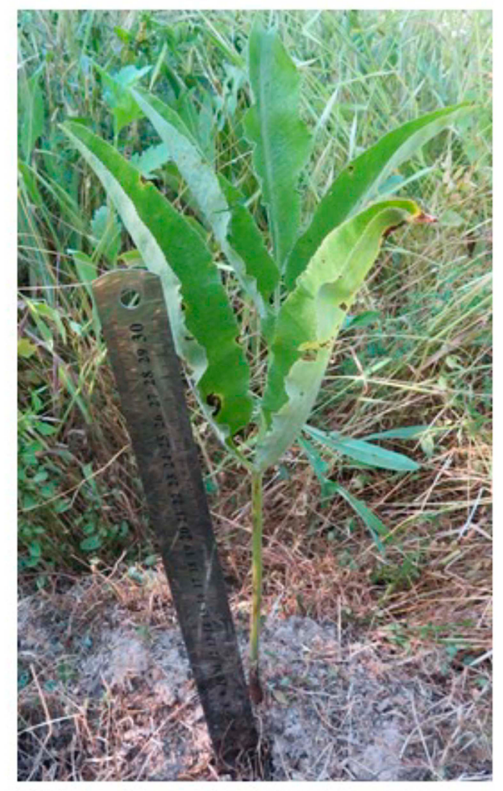

f

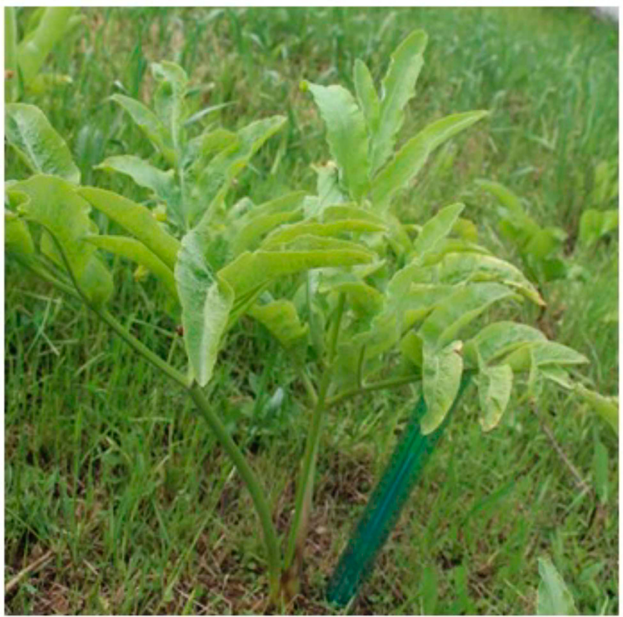

$\mathrm{h}$

Figure 2. Different-age plants of Ferula tadshikorum. e - immature plant of the third year (18.02.2021), $f$ - immature plant of the third year (22.04.2021), g - virginal plant of the first year (18.02.2021), h - virginal plant of the first year (22.04.2021).

\section{Conclusions}

The experience gained in the introduction of Ferula tadshikorum shows the prospect of growing this valuable species in the conditions of the Tashkent oasis, using standard agrotechnical techniques (watering and weeding). The results obtained can serve as a basis for the development of agricultural techniques for cultivation and zoning in various soil and climatic conditions of Uzbekistan in order to solve the current problems with the supply of raw materials for the pharmaceutical industry.

\section{Declarations}

Ethics approval and consent to participate: All participants involved in the interview process gave their prior informed oral consent.

Consent for publication: Not applicable.

Competing interests: The authors declare that they have no competing interests.

Funding: Not applicable. 
Availability of data and materials: The data was not deposited in public repositories but is available from the corresponding author upon request.

Authors' contributions: O.K. Khojimatov, D.T. Khamraeva A.K. Khujanov, and Z.Z. Kosimov collected and analyzed the data, drafted, and developed the manuscript. R.W. Bussmann critically revised the manuscript and expanded the ethnobotanical section. All authors contributed in the research, data collection, and approved the final manuscript.

\section{Literature cited}

Alqethami A, Hawkins JA, Teixidor-Toneu I. 2017. Medicinal plants used by women in Mecca: urban, Muslim, and gendered knowledge. Journal of Ethnobiology and Ethnomedicine 13:62 doi 10.1186/s13002-017-0193-4

Amiri MS, Joharchi MR. 2013. Ethnobotanical investigation of traditional medicinal plants commercialized in the markets of Mashhad, Iran. Avicenna Journal of Phytomedicine 3(3):254.

Ballabh B, Chaurasia OP. 2007. Traditional medicinal plants of cold desert Ladakh-Used in treatment of cold, cough and fever. Journal of Ethnopharmacology 112(2):341-349

Belolipov IV. 1989. The introduction of herbaceous plants of the natural flora of Central Asia: Introduktsiya travyanistykh rasteniy prirodnoy flory Sredney Azii. Tashkent. (in Russian).

Boboev T, Boboev MT, Saidov K. 2013. Rastanihoi gizoi va davoii Tojikistoni Janubi va rohhoi parvarishu muhofizati onho. Kulob, 48 p [In Tajik].

Bussmann RW, Batsatsashvili K, Kikvidze Z, Boboev M, Ghorbani A, de Boer H. - 2020. Ferula foetida Regel; Ferula kuhistanica Korovin; Ferula moschata (H. Reinsch) Koso-Pol.; Ferula violacea Korovin; Ferula sp. In: Batsatsashvili K, Kikvidze Z, Bussmann RW (eds) Ethnobotany of Mountain Regions Central Asia and Altai. Springer International Publishing International Publishing. doi: 10.1007/978-3-319-77087-1_60-1

Bussmann RW, Batsatsashvili K, Kikvidze Z, Paniagua-Zambrana NY, Moazzami Farida SH, Ghorbani A, Khutsishvili M, Maisaia I, Sikharulidze S, Tchelidze D. 2020. Ferula assa-foetida L. In: Batsatsashvili K, Kikvidze Z, Bussmann RW (eds.) Ethnobotany of Mountain Regions Far Eastern Europe. Springer International Publishing, Cham. doi: 10.1007/978-3-319-77088-8_59-1

Dayronas ZV, Zilfikarov IN, Vernikovsky VV. 2018. Development and standardization of medicinal herbal preparations from walnut leaves, Aromatic and medicinal plants: introduction, selection, agricultural technology, biologically active substances, impact on humans: Collection of scientific works of State Nikitsky Botanical Garden 146:153-158. (in Russian).

Dey A, Gorai P, Mukherjec A, Dhan R, Kumar Modak B. 2017. Ethnobiological treatments of neurological conditions in the Chota Nagpur Plateau, India. Journal of Ethnopharmacology 198:33-44

Ferubko EV, Kolkhir VK, Mondodoev AG, Nikolaev SM. 2010. Experimental study of the general pharmacological properties of dry marsh cinquefoil extract: Development, research and marketing of new pharmaceutical products: Collection of scientific papers, Pyatigorsk 65: 520-523. (in Russian).

Ferubko EV. 2018. Assessment of the antiulcer activity of a new complex plant extract under immobilization stress: Proceedings of the international scientific conference: In Vilar M (ed) Prospects for medicinal plant breeding 642647. (in Russian).

Grebennikova OA, Paliy AE, Rabotyagov VD. 2018. Biologically active substances Mentha longifolia, Aromatic and medicinal plants: introduction, selection, agricultural technology, biologically active substances, impact on humans: Collection of scientific works of State Nikitsky Botanical Garden, Yalta 146:146-152. (in Russian).

Gurib-Fakim A. 2006. Medicinal plants: Traditions of yesterday and drugs of tomorrow. Molecular Aspects of Medicine 27:1-93

Jan HA, Jan S, Bussmann RW, Wali S, Sist, F, Ahmad, L 2019. Complementary and Alternative Medicine Research, Prospects and Limitations in Pakistan: A Literature Review. Acta Ecologica Sinica. doi: 10.1016/j.chnaes.2019.12.005

Kaukhova IE. 2007. Theoretical and experimental foundations for the development of effective resource-saving technologies for herbal medicines: Abstr. Doct. Diss. SPb. 47 p. (in Russian).

Khamraeva DT, Khojimatov OK, Uralov Al. 2019. Growth and development of Ferula tadshikorum Pimenov under conditions of introduction: Acta Biologica Sibirica 5(3):172-177. (in Russian).

Khasina El. 2018. Anxiolytic effect of scabiozole patinia: Proceedings of the international scientific conference: In Vilar M (ed) Prospects for medicinal plant breeding 656-660. (in Russian).

Khojimatov OK, Khamraeva DT, Khujanov A. 2019. Assessment of the current state of some promising medicinal plants in Uzbekistan: Bulletin of Karshi State University 3 (41):Karshi 28-35. (in Russian). 
Khojimatov OK, Khamraeva DT. 2018. Study of the structure of the pericarp of the fruit of the valuable medicinal plant Ferula tadshikorum and the prospects for its cultivation in Uzbekistan. Uzbekistan Biological Journal 4:45-48. (in Russian).

Khojimatov OK, Maltsev II, Turginov OT. 2018. On the issue of stocks of the medicinal plant Ferula tadshikorum in Uzbekistan: Ecological Bulletin of Uzbekistan, Tashkent 1(201):24-26. (in Russian).

Khojimatov OK. 2005. Use of the medicinal flora of the South-Western Tien Shan by groups of diseases of the human body. Uzbekistan Biological Journal 6:50-54. (in Russian).

Khojimatov OK. 2019. Medicinal plants of Uzbekistan: their past, present and future: Food and Food Ingredients Journal of Japan 224(2):201-207. (in Russian).

Khojimatov OK. 2021. Medicinal plants of Uzbekistan (properties, application and rational use). Tashkent. 328 p. (in Russian).

Kiryalov NV. 1980. Dihydroconferin from Ferula tadshikorum. In Kiryalov NP, Sklar YE (eds) Chemistry of Natural Sciences 1:122-123. (in Russian).

Korovin EP. 1947. Illustrated monograph of the genus Ferula (Tourn.) L. - Tashkent: Publishing house of the Academy of Sciences of the UzSSR, 91 p. (in Russian).

Krasnov EA. 1997. Biologically active substances and the progress of medicine: Materials of the international scientific conference: Chemistry, technology and medical aspects of natural compounds. Almaty. 2007. 45 p. (in Russian).

Mozaffarian V. 2013. Identification of medicinal and aromatic plants of Iran. Farhang-e Moaser Publication, Tehran. Ontogenetic atlas of plants. Yoshkar-Ola: Mari State University, 1. (in Russian).

Quave CL 2013. Medicinal plant monographs. Emory University, Atlanta.

Rabotnov TA. 1950a. The life cycle of perennial herbaceous plants in meadow cenoses: Transactions of Botanical Institute of the Russian Academy of Sciences, Series 3(6), Geobotanika 7-204. (in Russian).

Rabotnov TA. 1950b. Questions of studying the composition of populations for the purposes of phytocenology: Problems of Botany. 1: 465-483. (in Russian).

Rakhmonov KS. 2017. Biology and Resources Ferula tadshikorum M. Pimen. in southern Tajikistan: Abstr. Doct. Diss. Dushanbe. 179 p. (in Russian).

Safina LK, Pimenov MG. 1984. Ferula of Kazakhstan: Alma-Ata. Science 110 p. (in Russian).

Saratikov AS, Krasnov EA. 2004. Rhodiola rosea (golden root): Tomsk. Publishing house Tomsk, 292 p. (in Russian).

Serebryakov IG. 1947. About the rhythm of seasonal development of the Moscow region forests: Bulletin of Moscow State University 6:75-108. (in Russian).

Serebryakov IG. 1961. The rhythm of seasonal plant development of the Khibiny tundra: Bulletin of Moscow Society of Naturalists. Department of biological Sciences 66(5):78-97. (in Russian).

Sharopov FS, Khalifaev PD, Satyal P, Sun Y, Safomuddin A, Musozoda S, Wink M, Setze WN. 2019. The chemical composition and biological activity of the essential oil from the underground parts of Ferula tadshikorum (Apiaceae). Records of Natural Products 13(1):18-23. doi: 10.25135/rnp.65.18.02.089

Sher, H., Bussmann, R.W., Hart, R., de Boer, H.J. 2016. Traditional use of medicinal plants among Kalasha, Ismaeli and Sunni groups in Chitral District, Khyber Pakhtunkhwa province, Pakistan. Journal of Ethnopharmacology 188:57-69. doi: 10.1016/j.jep.2016.04.059

Shishkin, B.K., 1951 (English 1974). Flora of the USSR, Volume 17: Umbelliflorae (continued) Peucedaneae-Dauceae \& Nyassaceae, Cornaceae; Akademia Nauk, Leningrad. 285 pages, 25 plates with b/w line drawings; 2 b/w fold-out maps.

Sokolov P.D. (ed.) 1988. Plant Resources of the USSR: Flowering plants, their chemical composition, use; Volume 4. Families of Rutaceae-Elaeagnaceae. Akademia Nauk, Leningrad, 357 p. (in Russian).

Titok V, Volodko I. 2012. Plant introduction and biological diversity: Science and Innovations 4(110):59-61. (in Russian).

Ur-Rahman, I., Sher, H., Bussmann, R.W. (Ed.) (2019). Reference guide on high value medicinal and Aromatic plants - sustainable management and cultivation practices. University of Swat, Pakistan (ISBN 978-969-23419-0-5).

Vandyshev VV, Sklyar YE, Veselovskaya NV Pimenov M.G. 1974. Coumarins of Ferula tadshikorum roots, Chemistry of natural connect. Tashkeny, Uzbekistan 4.

Zargari A. Medicinal Plants. Tehran, Iran: Tehran University Press; 1990. 